\title{
ANALYSIS EFFECT OF CONFLICT ROLE, SOCIAL SUPPORT TO ORGANIZATIONAL COMMITMENT AND IMPACT ON INTENTION TO QUIT
}

\author{
M. Fajar Chilman Najib \\ Master of Management, Faculty of Economics and Business, Diponegoro University
}

\begin{abstract}
Human resources (HR) is the only important organizational asset that can drive other resources. Human resources can affect the efficiency and effectiveness of the organization (Simamora, 2006). Secondary data in this research are: Data obtained from the management of PT. Bank Syariah Mandiri in the form of data turnover. Population in this research is employees of PT. Bank Syariah Mandiri Semarang, Jl. Pandanaran no. 90 a total of 137 employees. The method of collecting primary data is done by using documentation technique. Role conflict has a significant effect on the intention to quit. It is concluded that the greater the role conflict increases the intention to quit. The result of hypothesis 2 testing showing the role conflict has a positive effect on intention to quit is accepted, where high conflict can increase the intention to exit.

Organizational support has a significant positive effect on commitment. It is concluded that the greater the support the organization increases its commitment. Organizational support has a significant negative impact on intention to quit. It is concluded that greater organizational support decreases intention to quit. Commitment has a significant negative effect on intention to quit. It is concluded that the stronger the commitment can decrease the intention to quit.
\end{abstract}

Keywords: role conflict, social relationships, organizational commitment, intention do quit, Social support.

\section{INTRODUCTION}

Human resources (HR) is the only important organizational asset that can drive other resources. Human resources can affect the efficiency and effectiveness of the organization (Simamora, 2006). This is what makes the hotel business people aware of the value of employee investment as a human resource. Where to date collecting skilled and performing workforce is getting harder to do, 
moreover maintaining existing ones. They should prioritize finding, hiring, motivating, training, developing employees closest to the hotel culture and desired performance, and retaining qualified employees (Pophal, 2006).

This is where an important role of human resource management (MSDM) is required in a hotel business. Human resource management is an important activity in an organization. Organizations need to manage human resources to achieve their goals effectively, by constantly investing in the acceptance, selection and retention of potential human resources in order not to impact on employee movement (Anis et al., 2003).

Employee intention to quit (intention to quit) is a phenomenon that often occurs in the banking industry. Intention to quit can be interpreted as the movement of labor desires out of the organization. Intention to quit leads to the ultimate reality facing an organization in terms of the number of employees leaving the organization for a certain period, whereas turnover intentions refers to the results of individual evaluations of the continuation of relationships with organizations that have not yet been realized in the exact course of action leaving the organization. Turnover may include resignation, transfer out of an organizational unit, dismissal or death of an organization member.

Today the high level of intention to quit has become a serious problem for many companies. Woods and Macaulay (1989) point out that high turnover in the banking industry can disrupt operations, bring moral problems to living employees, and also incur costs in recruitment, interviews, tests, reference checks, new employee processing administration fees, benefits, orientation, and opportunity costs are lost as employees have to learn new skills. Rousseau (1984) adds that costs or losses on turnover include direct costs associated with recruitment activities (including advertising costs, agent fees) and search costs; indirect costs such as the cost of fees associated with training new employees; and productivity losses by new employee learning process.

Therefore, based on this description, this research entitled: "ANALYSIS EFFECT OF CONFLICT ROLE, SOCIAL SUPPORT TO ORGANIZATIONAL COMMITMENT AND IMPACT ON INTENTION TO QUIT"

\section{Formulation of the problem}

1. What is the effect of role conflict on commitment?

2. What is the effect of role conflict on intention to quit?

3. What is the effect of social support on commitment?

4. What is the effect of social support on intention to quit? 


\section{Research purposes}

1. Analyze the influence of role conflict on commitment

2. Analyze the influence of role conflict on intention to quit

3. Analyze the influence of social support on commitment

4. Analyze the influence of social support on intention to quit

5. Analyze the influence of commitment to intention to quit

\section{LITERATURE REVIEW}

\section{Intention to Quit}

Employee turnover or turnover is defined as the transfer of employees who cross the employee's membership limit in the organization initiated by the employee (Griffeth and Hom, 2004). An interesting aspect is the detection of motivational factors that will reduce the intention or desire of employees to leave the organization, because the intention to move is very strong influence in explaining the actual turnover. The existence of employees leaving the organization requires a large cost in the form of huge losses to experts who may also transfer the company's specific knowledge to competitors (Carmeli and Weisberg, 2006). Intention to quit is defined as someone's desire to leave the company. There are two factors why one chooses to quit his job, that is, because perceived desirability to leave the organization that employs it, is generally conceived as a factor of job satisfaction and organizational commitment, and because of the ease of leaving the organization (perceived ease) in general conceived as the quality of alternative work (Long et al., 2012).

Intention to quit is the tendency or intention of the employee to get out of where he works voluntarily according to his own choice, and to think of getting out of his job if he can get another better job (Ngo et al., 2015). This intention is still an intention, not yet something materialized. If the employee is out and can be counted, it can be said that Intention to quit has occurred, so that before intention to quit occurs, then when the intention is formed, from this early phenomenon, a bank / organization must be sensitive to the vulnerable symptoms happening to its employees.

The types of intention to quit are usually classified as voluntary or voluntary. Intention to quitsukarela occurs when the workforce leaves the organization at its own request due to several factors. Less challenges, better chances elsewhere, salary, surveillance, geographical position and pressure, all of which can be a trigger of stress are some of the factors that serve as the reason for someone out of the bank where he works. Certainly not all intention to quitnegatif. Losing some 
labor is sometimes desirable, let alone the labor that goes is low-performing / low productivity (Carmeli and Weisberg, 2016).

\section{Commitment}

Organizational commitment to work in organizations has a significant relationship with job perceptions of organizational commitment to work (perceived organizational support) in exchange for perceptions of organizational behavior of their attitudes and behavior (Carmeli and Weisberg, 2016).

Organizational commitment is a manifestation of one's willingness in the form of self-bonding (individual organizational commitment) or with its organization (organizational commitment), illustrated by the magnitude of effort (the amount of energy, time and thought) or the magnitude of the spirit to continue learning for the achievement of the ideals. personal commitment (individual organizational commitment) or shared vision / organizational commitment (Glismeyer, 2015).

Organizational commitment variables fall into three categories: (1) the characteristics of personnel of each member of the organization that includes age, education, gender and the need for achievement; (2) job-related characteristics consisting of several variables such as role emphasis (conflict and unclear role) and (3) task characteristics and work experience that include variables such as leadership attitudes (initiative from the organization and consideration of leaders) and organizational structure formalization and participation in decision making). Considering that the focus of this research is on organizational factors, this study is limited to work-related characteristics and work experience. Although both variables are expected to be related to the given sample, at the same time, it is possible that the worker holds positive trust and love for the organization and its purpose and value, but does not like the execution of certain aspects of a particular job in the organization and vice versa (Carmeli and Weisberg, 2016).

\section{Role Conflict}

Robbins (2015) defines conflict as a process that begins when one party has a perception that the other has negatively influenced, or will negatively influence, something of first interest and interest. A person will experience role conflict if he or she has two or more roles to perform at the same time. Idris (2014) shows that role conflict is capable of declining organizational commitment.

From some of the above description it can be concluded that role conflict arises when employees find it difficult in terms of adjusting the various roles possessed at the same time, for example the role of an organization that must be responsible for the organization bureaucracy and its role as head/housewife who must responsible to his family (Glismeyer, 2015). 


\section{Social Support}

Social support is defined as information from other people who convince someone that they are loved, cared for, and valued (Lee, 2014). Taylor also added that social support can come from parents, spouses or lovers, other relatives, friends and contact with the community. Someone with a high level of social support will reduce the possibility of stress when they are faced with a stressful situation. Lee (2014) states that social support has a positive effect on commitment.

A similar definition also stated by Lee (2014) social support is a feeling of comfort, attention, appreciation, or assistance received from other people or groups. Sarafino added that people who receive social support have the belief that they are loved, valued, and are part of a group that can help them when they need help.

Figure 1

Research Framework

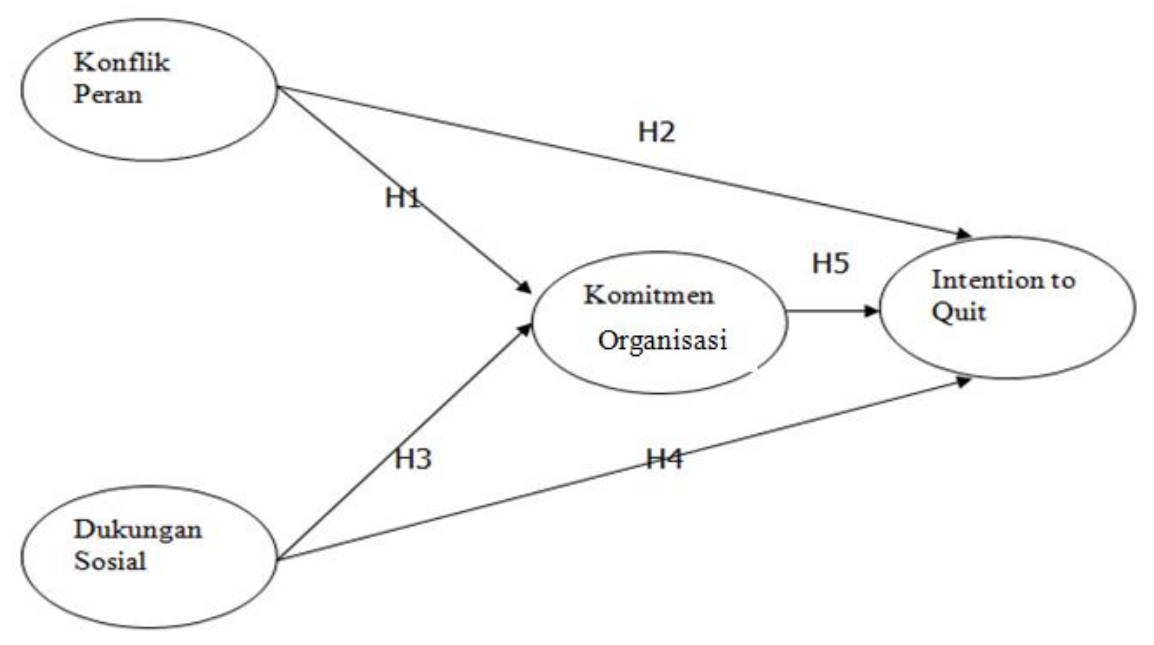

\section{RESEARCH METHOD}

\section{Population and Sample}

Population in this research is employees of PT. Bank Syariah Mandiri Semarang, Jl. Pandanaran no. 90 a total of 137 employees. The sample in this research is 1 employee of PT. Bank Syariah Mandiri Semarang, Jl. Pandanaran no. 90. 


\section{Sampling technique}

In this study conducted a test using 30 respondents to determine the feasibility of the questionnaire.

\section{Data Collection Procedures}

The method of collecting primary data is done by using documentation technique. The data in the form of respondent's opinion about the research variable is measured on a scale of $1 \mathrm{~s} / \mathrm{d} 7$ for STS's opinion s / d SS.

\section{Analysis Technique}

Data analysis technique used is Structural Equation Model from AMOS statistic package. As a model of structural equation, AMOS is often used in strategic marketing and management research (Ghozali, 2015). The AMOS causal model shows structural measurements and problems, and is used to analyze and test hypothetical models. According to Ghozali, (2015) AMOS has privileges in:

1. Estimate the unknown coefficients of the structural linear equations

2. Accommodate a model that includes a variable latent

3. Accommodate the measurement error on the dependent and independent variables

4. Accommodate mutual, simultaneous and interdependent warnings.

This research will use 2 step approach analysis technique that is:

1. Confirmatory Factor Analysis (CFA) in SEM is used to confirm the most dominant factors in one group of variables.

2. Regression Weight on SEM used to examine how big the relationship between variables.

\section{DATA ANALYSIS AND DISCUSSION}

\section{Respondents' Overview}

Respondents in this study are employees of PT. Bank Syariah Mandiri Semarang Pendanaran No.9, the number of 114 respondents.

\section{Table 1}

\section{Hypothesis Summary}

\begin{tabular}{l|l}
\hline \multicolumn{1}{c|}{ Hypothesis } & \multicolumn{1}{c}{ Result } \\
\hline H1: Role conflict negatively affects commitment & Accepted \\
\hline H2: Role conflict positively affects the intention to quit & Accepted \\
\hline H3: Social support positively affects commitment & Accepted \\
\hline H4: Social support negatively affects intention to quit & Accepted \\
\hline H5: Commitment negatively affects the attention to quit & Accepted \\
\hline Source: processed primary data &
\end{tabular}




\section{Conflict Relationships Roles and Commitments}

The result of hypothesis 1 testing showing role conflict negatively affects organizational commitment so it can be accepted, where strong commitment from employees indicating strong desire to continue to be part of organization will be supported by low role conflict. If an employee experience high role conflict against a company or work then what happens is that the employee will experience a decrease in commitment on the job that causes the employee's desire to leave his job.

According to Glissmeyer, (2015), role conflict is a conflict that occurs because someone carries more than one conflicting role. Idris (2014) says that role conflict is that people have conflicting or inconsistent expectations. Role conflict arises when a person receives an incompatible message with respect to the appropriate role behavior.

\section{Conflict Relation Roles and Intention to Quit}

The result of hypothesis 2 testing showing role conflict positively influence to intention to quit accepted, where the employee with high conflict can increase intention to exit. If an employee has a high role conflict then what happens is that the employee will think to quit the job.

Employees often face conflicting demands between work and the family, for example women experience a larger role conflict than men between work and family because women are essentially housewives with responsibilities to their husbands and children. Unmarried employees also have a version of their own role conflict between work and outside interests. Role conflict can also be experienced when the internalization of values, ethics or personal standards contradicts the expectations of others.

The results of this study have also been in accordance with research conducted by Glissmeyer, (2015), and Idris (2014) stating that the greater the role conflict faced will make employees feel uncomfortable, this will increase employee desire to leave his job. So research conducted by Glissmeyer, (2015), and Idris (2014) states that role conflict has a positive influence on intention to quit.

\section{Social Support Relationships and Commitment}

The result of hypothesis 3 testing shows that social support has a positive effect on organizational commitment accepted, where employees with supported organization will feel comfortable in work because of increased working pressure, this is able to increase its commitment. Social support can provide assistance to employees in the form of comfort, attention, the perceived individual can have a positive effect for himself obtained through interaction with other individuals or 
groups so that the employee will feel comfortable so will continue to commit to his work.

Social support arises from the perception that there are people who will help in the event of a situation or event that is seen to cause problems and the aid is felt to raise positive feelings and lift self-esteem. This condition or psychological state can affect individual responses and behaviors in order to affect the welfare of individuals in general.

\section{Social Support Relationships and Intention to Quit}

The results of hypothesis 4 testing that show social support negatively affect the intention to quit accepted, where employees supported the organization will feel comfortable in work because of increased employment pressure will decrease the intention to get out. Employees who experience intention to quit will greatly require the presence of others to pay attention and give affection. Employees need good support from colleagues, family, when faced with a problem, so will feel that the pressure faced is not felt by himself, but there are others who help him.

With the existence of social support, is expected to give a positive influence to employees, among others, can lead to inner calm, encouraging work and cause confidence so that nurses can do their job well. The results of this study have also been in accordance with research conducted by Lee (2014) states that social support negatively affect intention to quit.

\section{Relationship Commitment and Intention to Quit}

The results of hypothesis testing 5 showing organizational commitment negatively affect the intention to quit accepted, where a strong commitment from employees showed a strong desire to continue to be part of the organization sehinggan will reduce the intention to exit. Organizational commitment to this organization is about the pride of employees against work and become part of the organization where work, so that in the implementation of duties as part of the organization, workers have organizational commitment to contribute best for the organization. So that if the employee has a strong commitment to the company / work then the employee will not have the intention to make the movement of work.

Organizational commitment can be defined as the degree that a person identifies himself as part of the organization and desires to continue active participation in it. Organizational commitment refers to identification with organizational goals, the ability to exert all power for the benefit of the organization, and the interest to remain part of the organization (Mowday, Steers \& Porter, 1982). 
The results of this study have also been in accordance with research conducted by Tett and Meyer, (1993), in his research examined the effect of organizational commitment on intent to exit, where the results showed that employees who lack a strong commitment to the organization will be easy to get out of work, it can be concluded that organizational commitment has a negative effect on the intention to exit. In addition, Carmeli and Weisberg, (2016) also stated similarly that by demonstrating a high commitment can lower intention to quit.

\section{CONCLUSIONS AND IMPLICATIONS}

\section{Conclusions}

Role conflict has a significant negative impact on commitment. It is concluded that the greater the role conflict can reduce its commitment. The results of hypothesis 1 testing that show role conflict negatively affect organizational commitment is accepted, where strong commitment from employees indicating strong desire to continue to be part of organization will be supported by low role conflict.

Role conflict has a significant effect on the intention to quit. It is concluded that the greater the role conflict increases the intention to quit. The result of hypothesis 2 testing showing the role conflict has a positive effect on intention to quit is accepted, where high conflict can increase the intention to exit.

Organizational support has a significant positive effect on commitment. It is concluded that greater organizational support increases its commitment. The results of hypothesis 3 testing that show organizational support have a positive effect on organizational commitment are accepted, where employees with large organizational support are able to increase their commitment.

Organizational support has a significant negative impact on intention to quit. It is concluded that the greater the organizational support decreases the intention to quit. The results of hypothesis 4 testing show that organizational support negatively affects the intention to quit is accepted, where employees with large organizational support will decrease the intention to exit.

Commitment has a significant negative impact on intention to quit. It is concluded that the stronger the commitment can decrease the intention to quit. The results of hypothesis testing 5 showing organizational commitment negatively affect the intention to quit accepted, where a strong commitment from employees shows a strong desire to continue to be part of the organization sehinggan will reduce the intention to exit. 


\section{Implications}

The policy implications in this study can be suggested through the following points:

1. Management of PT. Bank Syariah Mandiri is always trying to improve the welfare of employees by providing salary and incentives according to the achievement of targets, THR, leave allowances and life insurance / health, it can reduce role conflict.

2. Management of PT. Bank Syariah Mandiri provides faster promotion opportunities for those with the potential to have skills as employees. It will increase commitment and lower intention to quit.

3. Management of PT. Bank Syariah Mandiri provides overtime for employees overtime on holidays (Saturday, Sunday, big day). It will decrease role conflict, where employees feel comfortable.

4. Management of PT. Bank Syariah Mandiri needs to provide equal rewards for employees who achieve the target according to the provisions. Reward obtained in the form of a ticket to the country (Around the World) is done a year $4 \mathrm{x}$. This is to lighten the workload of employees, where employees will feel more appreciated.

\section{REFERENCES}

Abbasi, Tajmal Farooq (2015) "Impact of Work Overload on Stress, Job Satisfaction, and Intention to quits with Moderating Role of Islamic Work Ethics," Management Studies and Economic Systems (MSES), Vol. 2 (1), pp. 27-37.

Aprila, N. 2005. Pengaruh Komitmen Organisasi, Kepuasan Kerjadan Keperilakuan Etis Terhadap Keinginan Berpindah Pada Profesional Bidang Teknologi Informasi. Jurnal Bisnis \& Manajemen, 5(1).

Carmeli, Abraham dan Jacob Weisberg, 2016, "Exploring Intention to quit among Three Professional Groups of Employees", Human Resource Development International, Vol.9, No.2,pp. 191-206.

Chang, C. P. 2008. Internal Marketing Practices and Employees' Turnover Intentions In Leisure Hotels. The Journal of Human Resource and Adult Learning, 4(2).

Chao Chih Yang; Huang Yi Li dan Lin Chih Wei, (2010), "The relationship between leadership behavior a principal and work life of teachers in an industrial vocational high school in Taiwan," National Changhua University, Vol 2, No 8, pp 103-138. 
Eric. S. William, Thomas. R, Konrad. William E. Scheckler, Donald E. Mc Murray, Martha Gernity and Mark Schwarz. 2011,"Understanding Psysicions" Intention to withdraw from practice: The Role Of Job Satisfaction, Job Stres, Mental, and psysical Health," Health Care Management Review. Vol 3, pp. 1-34.

Fuad Mas'ud, 2004, Survei Diagnosis Organisasional, BP UNDIP, Semarang

Ghozali, 2015, Aplikasi analisis Multivariate dengan Program SPSS, Badan Penerbit UNDIP , Semarang.

Gliemeyer Michael., James W. Bishop dan R. David Fass 2015, "Role Conflict, Role Ambiguity, And Intention To Quit The Organization: The Case Of Law Enforcement Officers" Journal of the Institute of Mangement Science, Vol. 4, pp. 35-78.

Hair, J. F., Anderson, R. E., Tatham, R. L. \& Black, W. C. (1998). Multivariate data analysis, Fift Edition. Prentice-Hall International, Inc. New Jersey.

Hwang, Ing-San, Dr. dan Jyh-Huei Kuo, 2016, "Effects of Job Satisfaction and Perceived Alternative Employment Opportunities on Intention to quit - An Examination of Public Sector Organizations", The Journal of American Academy of Business, Cambridge, Vol.8, pp. 1-52, March.

Idris, Mohd Kamel (2011) "Over Time Effects of Role Stress on Psychological Strain among Malaysian Public University Academics," International Journal of Business and Social Science, Vol.6, pp. 102-141.

Lee, Patrick Chang Boon 2014."Social support and leaving intention among computer professionals," Information \& Management, Vol. 41, pp. 323334. 